\title{
LEHETŐSÉGEK A PROBLÉMAORIENTÁLT FÖLDRAJZOKTATÁS HATÉKONY- SÁGÁNAK NÖVELÉSÉRE A PÉCSI TUDOMÁNYEGYETEM TEREPASZTALA SEGÍTSÉGÉVEL
}

\author{
THE ROLE OF THE GEOMODEL AT UNIVERSITY OF PÉCS ON ENHANCING THE EFFICIENCY OF \\ PROBLEM-BASED GEOGRAPHY EDUCATION \\ CZIGÁNY SZABOLCSa - NAGYVÁRADI LÁSZLÓ - PIRKHOFFER ERVIN - \\ HALMAI ÁKOS - KLIMÁSZ KITTI - KISS KINGA - M. CSÁSZÁR ZSUZSANNA \\ - VARJAS JÁNOS \\ Pécsi Tudományegyetem Földrajzi Intézet \\ a sczigany@gamma.ttk.pte.hu, b cszsuzsa@gamma.ttk.pte.hu
}

\begin{abstract}
Small-scale modelling is a widespread method for the simulation of large-scale natural processes in the fields of hydrology, hydraulics, geology, geomorphology and river mechanics. At the University of Pécs a computer-controlled sand table (hydrologic and tectonic geomodel) was put into operation in 2014 for both research and educational purposes. The table can be tilted at any arbitrary angle between $\pm 7.5^{\circ}$ along its longitudinal axis, and by $\pm 10^{\circ}$ along its transversal axis. Lateral deformation of the medium is simulated through the displacement of four lateral pushblades to the extent of $100 \mathrm{~mm}$. The four interior units can be uplifted to model orogenic processes. All motions in the flume are executed by computer-governed electroengines. Geomodels, flumes and stream tables may ease the understanding of geographic processes through problem-oriented based teaching methods and hand-on-experiences. The benefits of problem-based learning (PBL) have also been confirmed during the visits of various age groups at the geomodel. Our observation during these demonstration sessions revealed one of the major weaknesses of the Hungarian educational system, i.e. teachers are forced to follow the conventional geographical curricula, therefore hindering their adaptation to cutting-edge educational methods and the learning-by-doing approach of the Western European and North American syllabi.
\end{abstract}

Keywords: computer-controlled geomodel, problem-based learning, geography education, popular science

\section{Bevezetés}

A világban történt eseményekről szinte azonnal tájékozódunk a médiának köszönhetően, így a természeti katasztrófákról is. Arról azonban kevés információt szerezhetünk, hogy mekkora felelőssége van ebben az emberiségnek, pedig már kutatások bizonyították, hogy az antropogén hatások teljesen átformálták, egyre inkább átformálják környezetünket, növelik a természeti veszélyeket és hozzájárulnak az éghajlatváltozáshoz. E téren a földrajzoktatásra komoly feladat hárul; a médiában terjedő álhírekkel szemben a lejátszódó folyamatok okainak és következményeinek feltárására kell fókuszálnia. Azonban 
az oktatásban annak is meg kell jelennie, hogy miként tudjuk megelözni vagy mérsékelni a természeti és környezeti katasztrófák okozta károkat.

A fizikai kisminta modellek napjainkban újra reneszánszukat élik. Ez a folyamat részben annak is köszönhetö, hogy a hidrológiai modellek egyre bonyolultabbak és egyre nehezebben kezelhetőkké váltak, illetve hogy a számítógépes reprezentációk egyre magasabb dimenziószámú megközelítéseket alkalmaznak (Jonassen, D. H. - Reeves, T. C. 1996), emiatt nagy számolási kapacitást igényelnek például drága szuperszámítógépek segítségével. Így a fizikai kisminta modellek, mint például a geomodellek, terepasztalok vagy áramlási modellek fontos eszközei lehetnek a problémaalapú oktatásnak, amelynek térhódítása az angolszász világban és Nyugat-Európában egyre nyilvánvalóbb. Ugyanis napjainkra egyértelművé vált, hogy a hagyományos oktatási módszerek egyre kevésbé hatékonyak, szükség van az innovációra, demonstrációra, valamint ezek során egy irányított tudásátadásra az új típusú tanuláshoz (Spronken-Smith, R. et al. 2007; 2011; 2012). A munkaerőpiacon nem az ismeret jellegü tudásnak van prioritása, hanem sokkal inkább a képességeknek, készségeknek, mint például a problémamegoldás képessége vagy alkalmazkodóképesség. Nem véletlen, hogy a PISA tesztek - amelyek 2000 óta háromévente mérik a diákokat - a tudás mellett kompetenciákat, például 2003-tól a komplex problémamegoldó képességet is mérik. Ilyen típusú gondolkodáshoz egyértelmüen szükség van a tanulók aktivizálására, együttmüködésére, ehhez pedig újfajta tanulási-tanítási módszerekre, mint a problémaalapú, kutatásalapú vagy dizájnalapú tanulás.

A problémaalapú tanulás - Problem Based Learning, rövidítve PBL - az orvosképzésben jelent meg először az 1960-as években, ahol diagnosztikai eljárásokban alkalmazták, majd átvette ezt a jogi, a müszaki és a szociálismunkás-képzés is. A természettudományok oktatása során a kurzusok bevezető óráin alkalmazzák (AlLEN, D. E. et al. 1996). A neveléstudományban egyrészt tanítási-tanulási módszer (BARRows, H. S.-TAMBlYN, R. M. 1980), másrészt egyes kutatók (WaLton, H. J. - Matthews, M. B. 1989) szerint oktatási stratégia, ahol a tanulók csoportokra bontva közösen oldanak meg egy életből kölcsönzött problémát; ehhez meg kell ismerniük a szóban forgó tudományterület ismeretanyagát, módszertanát, és építeniük kell elözetes tudásukra. A gyakorlatból vett példákkal úgy alakíthatjuk a tananyagot, hogy az motiválja a tanulókat (Boud, D. - FeletTi, G. 1991, 1997). A tanulás hajtóereje maga a probléma, illetve annak megoldása lesz, így egy rendkívül sajátos, de célravezető tanulási környezet jön létre. A PBL módszer nagy újitása, hogy a diákok nem a már elsajátított tanagyag gyakorlása céljából oldanak meg problémát, hanem az információk megtanulásának része a probléma (MolNÁR GY. 2004). Ennek köszönhetően fejlődik a 
tanulók kritikai, analitikus és kreatív gondolkodása is (ARTs, J. A. R. et al. 2002). A módszer hatékonyságát növelhetik a különböző infokommunikációs technikák, hiszen a világháló rengeteg lehetőséget nyújt a tájékozódásra. Érezhető emellett, hogy a PBL összeköthető a kutatásalapú tanulással, a projektmunkával, illetve a csoportban dolgozás lehetősége miatt a kooperatív technikákkal is. Mivel a diákok aktivizálódnak, maguk keresik a válaszokat és építik fel tudásukat, így a tanár szerep is változik, már nem a tudás egyedüli átadója lesz, hanem a csoportos folyamatokat, megbeszéléseket elősegítő folyamatvezető (facilitátor) szerepét tölti be (SpronkeN-SMith, R. et al. 2007; idézi NAGY L.-NÉ 2010).

A dizájnalapú tanulás - Design Based Learning, rövidítve DBL - esetén a tanulók tudományos kísérletek tervezésében, sőt fejlesztésében vesznek részt (ANDERson, R. D. 2006). A kutatásalapú tanulást (Inquiry Based Learning, rövidítve IBL) többen (BARRON, B. D. - HAmmond, L. 2008; WATson, M. 2008) tekintik a legátfogóbb módszernek, míg legkiterjedtebbnek a projektalapú tanulást, amely keretet nyújthat az összes önálló, megfigyeléses, problémamegoldó tanuláshoz (Schraw, G. et al. 2006). Mindhárom hasznos eszköze lehet a konstruktív pedagógiának, amely egyébként az elmúlt évtizedben számos ún. learningby-doing módszert publikált. Ezek a tárgyalt adaptációk és alkalmazások remek példák a tudásalapú tanulásirányítási módszer újfajta megközelítéséhez (AGNEW, C. 2001).

\section{Kutatási célú kísérletek a terepasztalon és geomodelleken}

A geográfia multidiszciplináris tudomány, a tér tudománya. Vizsgálati tárgya a földrajzi burok: vizsgálja, elemzi és szintetizálja a földrajzi jelenségeket, folyamatokat és a közöttük lévő összefüggéseket. A geomodellek leképezik a valódi földrajzi folyamatokat numerikus számítógép alapú modellekre, terepasztal és kísérletek segítségével (NorTON, S. N. et al. 2007, Bertalan, L. et al. 2016). Ezek a modellek tehát megfelelő alkalmazással hozzájárulhatnak a szintetikus tudás fejlesztéséhez. A technika és az általa létrehozott modellek segítségével könnyebben megérthetjük többek között a folyóvízi geomorfológia kérdéseit. Az oktatás céljaira is kiválóan alkalmazhatók ilyen modellek, hiszen a többoldalú kutatások eredményeit felhasználva különböző környezeti folyamatok elemzését tehetjük meg, egybekötve az innovációs oktatás elemeivel (HeAley, M. - Jenkins, A. 2000).

Kutatócsoportunk tíz éve foglalkozik árvízi modellezéssel térinformatikai-hidrológiai numerikus modellek segítségével (PIRKHOFfER E. et al. 2008, 2013; Czigány Sz. et al. 2009; Hegedüs P. et al. 2013). Azonban a kutatások több problémára is felhívták a figyelmet a modellezés szemszögéből. Egyrészt szinte lehetetlen 
olyan részletes monitoringhálózatot kiépíteni, ami hibamentesen reprezentálja az adott vízgyüjtő modellezés szempontú paramétereit, másrészt a nagyvízi rendszereken alkalmazott konstansok, empirikus összefüggések nem feleltethetők meg a kisvízi rendszerekben alkalmazott modelleknek. A sztochasztikusság szintén nem programozható az elörejelzésekben. Kutatócsoportunk ezért kialakított egy fizikai kisminta modellrendszert, ahol ellenőrzött körülmények között, számítógépes támogatással modellezhetők árvízi, talajnedvesség-dinamikai, fedettségi, felszínhasználati, hosszabb távon pedig a mederfejlődési és tektonikai folyamatok is. Erre, az összetett kísérletsorozatok lehetőségére utal a rendszer Tektonikai és Hidrológiai Szimulációs Projekt (Project for Tectonical and Hydrological Simulations, mozaikszóval rövidítve PTETHYS) neve is. Tanulmányunkban ezt a terepasztalt kívánjuk bemutatni, amelyen a tanulókkal együttesen végzett kísérletek hozzájárulhatnak a különböző problémaorientált tanulási módszerek segítségével a magyar földrajzoktatás megújításához. Iskolai osztályokat szeretnének a terepasztalhoz csábítani, kihelyezett földrajzórákat tartani számukra, amelyek tapasztalatairól egy következő tanulmányban számolunk be.

\section{A geomodell általános jellemzői}

Alapvető célkitüzésünk az volt, hogy egy olyan fizikai kisminta modellt, terepasztalt, geomodellt, áramlástani terepasztalt (flume) hozzunk létre, ami nemcsak a folyamatok modellezésére, hanem annak teljes számítógépes feldolgozására is alkalmas, valamint lehetőséget teremt általános és középiskolai földrajzóra keretein belül történő gyakorlati oktatásra. Projektünk kezdetén megvizsgáltunk más hasonló fizikai kisminta modellt is (EM4 geomodel, http://www.emriver.com), azonban az nem felelt meg teljesen az elvárásainknak. Ennek következtében egy saját tervezésű terepasztal elkészítése mellett döntöttünk. A terepasztal elkészítésénél fontos szempont volt, hogy ne csak hidraulikai, hidromorfológiai és áramlástani kísérleteket tudjunk elvégezni, valamint demonstrálni, hanem tektonikai események bemutatására is alkalmas legyen a készülék.

Az modelltér tervezését a Pécsi Tudományegyetem Földrajzi Intézete, valamint a Pollack Mihály Müszaki és Informatikai Kar Gépszerkezettani tanszéke készítette. A teljes műszaki dokumentációt a kivitelezést, valamint az üzembehelyezést a CsavarKONTROLL 2004 KFT (Dunavecse) végezte el. A terepasztal műszaki paramétereit az 1. táblázat mutatja be. A modelltér minden mozgatási mechanizmusa számítógéppel, programozottan vezérelt, léptető elektromotorok segítségével (1. ábra). Ez lehetővé teszi mind a nagyon lassú, 


\begin{tabular}{l|l}
\hline Méret $(\mathrm{m})$ & $4,2 \times 2,5$ \\
\hline Teherbírás $(\mathrm{t})$ & 2,5 \\
\hline Hossztengely menti maximális dönthetóség $\left(^{\circ}\right)$ & $\pm 7,5$ \\
\hline Kereszttengely menti maximális dönthetőség $\left(^{\circ}\right)$ & \pm 10 \\
\hline Asztalfelület 6 tektonikai elemének vertikális emelési tartománya $(\mathrm{mm})$ & \pm 120 \\
\hline Oldalirányú 4 db tolólap maximális vízszintes elmozdulása $(\mathrm{mm})$ & 750
\end{tabular}

1. táblázat. A terepasztal föbb müszaki paraméterei

mind a nagyon gyors változások modellezhetőségét. A mozgások mértékének külső kontrolálása Leica Disto D3aBT lézeres távmérőkkel történik. A terepasztalba töltött médium, illetve üledék szín és sürüség, valamint szemcseméret alapján osztályozott homokkal történik. A szürke és fekete szemcsék anyaga 1 , illetve $0,8 \mathrm{~mm}$-es szemcseméretü bazalt- és andezitőrlemény. A 0,6 mm-es osztályban vörös márványt, míg a 0,2 mm-es mérettartományban bézs színü mészkövet alkalmazunk.

A folyamatok időbeli változásnak követésére két megközelítést alkalmazunk. Egyrészt detektáljuk a kísérlet összes képi információját, valamint a modelltérben lejátszódó folyamatok fizikai paramétereit. A kísérlet lefolyását $8 \mathrm{db}$ overhead CANON 1110 D fényképezőgép dokumentálja. A gépek egy konzolrendszeren helyezkednek el (2. ábra), egymástól változtatható távolságban, alapbeállításban $30 \mathrm{~cm}$-es térközben és 1,2 m-es magasságban. A képek közötti átfedés 18 -as gyújtótávolságnál megközelítőleg $80 \%$, ami lehetővé teszi a 3D-s képalkotást, illetve terepmodell elkészitését. A fényképezőgépek USB összeköttetésen keresztül, saját fejlesztésű (CANON SDK alapú) szoftverrel vezéreltek.

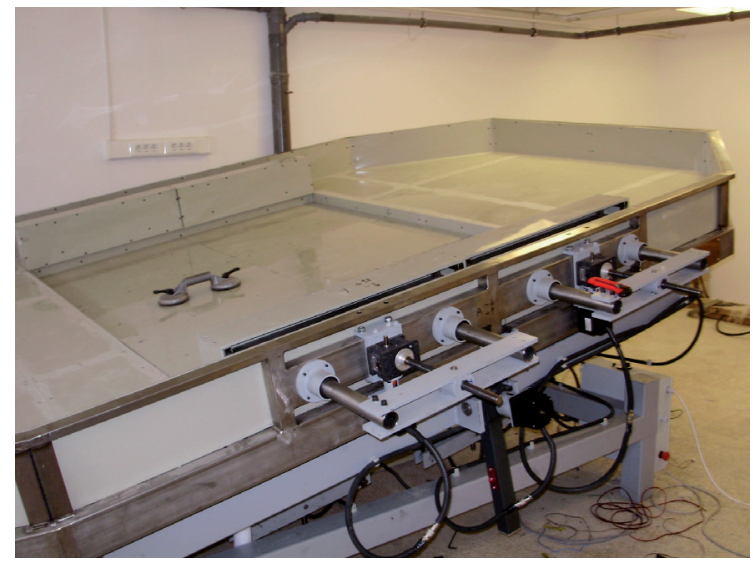

1. ábra. A modelltér feltöltés elötti állapotában, a villanymotorok és a dönthetöség a felső határon 
A hidraulikai, hidromorfológiai kísérletekben a mozgó víz valódi helyzetét (a mindenkori aktív meder, medrek elhelyezkedését), a vízsebességeket, valamint a talajnedvesség horizontális trendjét egy Varioscan 3021 ST típusú hőkamerával határozzuk meg. A kamera érzékelési tartománya $8-12 \mu \mathrm{m}$, hőmérsékleti felbontása $\pm 0,003^{\circ} \mathrm{K}$. A talajnedvesség idő szerinti változását, valamint a nedvesedési front mozgását Decagon gyártmányú (Decagon Devices Inc./Meters Group, Pullman, WA, Egyesült Államok) 10 HS TDR rendszerű szenzorokkal mérjük és az adatokat ugyancsak Decagon típusú EM50 adatgyüjtőkkel tároljuk. A képfeldolgozáshoz, a sztereoképek kialakításához, valamint a domborzati leképezéséhez Agisoft PhotoScan programot használunk. A domborzati modell kiértékeléséhez, valamint a folyamatmodellek vizsgálatához ArcGIS 10.2-es szoftvert alkalmazunk.

\section{A terepasztal alkalmazási lehetőségei}

A terepasztal mint fizikai kisminta modell segítségével kvantitatív morfológiai és morfometriai kísérletek végezhetők, amelyek során meghatározható például hordalékkúpok növekedési sebessége a táplálóterület nagysága, anyagi minősége, meredeksége, valamint a csapadék mennyisége és intenzitása függvényében (3A. ábra). Természetesen más hidraulikai és hidromorfológiai kísérletek is elvégezhetők a terepasztal segítségével, mint például parterózió, magaspartok alámosásának modellezése, illetve mederfejlődés és meanderek lefüződése. A tektonikai kisérletek elsősorban (kvázi)plasztikus, deformálható közegekre alkalmazhatók (3B ábra). Ezek alkalmazhatósága újszerủ és jelentős többletinformációt nyújthat szerkezetföldtani vizsgálatokhoz, valamint tektonikai és szerkezettani folyamatok modellezésére és változásuk, illetve irányuk elörejelzésére.

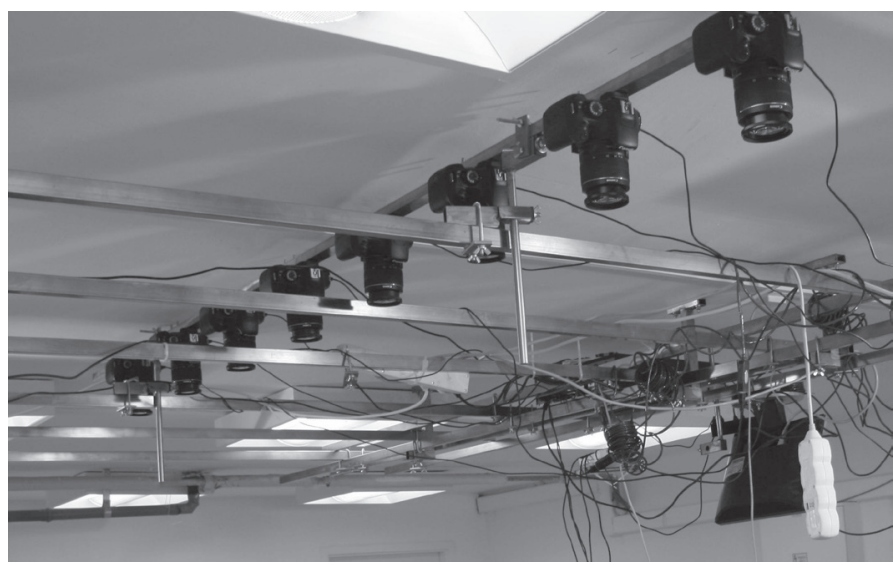

2. ábra. Nyolc overhead fényképezögép a folyamatok rögzitésére, 3D-s képalkotáshozés domborzati modell készitéséhez 


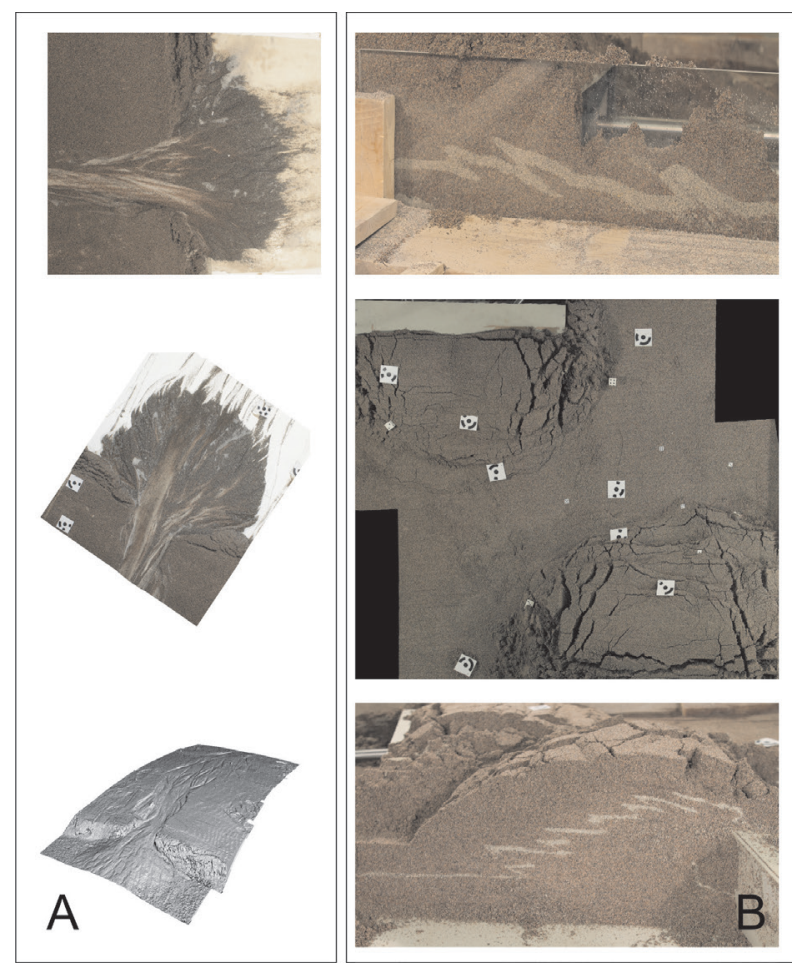

3. ábra. Hidrológia és áramlástani kísérletek eredményei, valamint a kísérlet alapján létrehozott terepmodell (A), illetve egy tektonikai kísérlet eredményei a PTETHYS geomodell segítségével (B)

\section{Problémaorientált földrajzoktatás a Pécsi Tudományegyetem terepasztalával}

A Pécsi Tudományegyetem Földrajzi Intézetében müködő terepasztal segítségével bemutathatók és vizuálisan szemléltethetők különböző víz- és mederkezelési problémák, a folyómedrek vándorlásának, valamint a hordalékkúpok épülésének környezetre gyakorolt hatása. A kísérleteket már számtalan korosztály megtekintette az óvodás gyerekektől a nyugdíjas csoportokig. Ez a fajta vizualizációs élmény sokkal életközelibb és gyakorlatiasabb jártasságot biztosít a geomorfológiai és vízföldrajzi ismeretekben, mint a hagyományos tantermi, tradicionális elméleti oktatás. A geomodell kísérlet a hidrológiai folyamatok megértése és vizuális tapasztalatok szerzése mellett a felszínfejlődési folyamatok megértésében is segítheti a diákokat, valamint aktív, közvetlen gyakorlati tapasztalaton alapuló (hand-on-experience) tanulási környezetet indukál. A terepasztal használatának fontos hozadéka, hogy a diákok a kísérlet révén rendszerben látják a természeti folyamatokat, sőt ők maguk részt vesznek a rendszer 
megtervezésében, módosításában, kalibrálásában, ellenőrzésében, miközben megtanulják a szaknyelvet, és fejleszthetik az elemzési és szintetizálási képességeiket a szimuláció elkészítésével és folyamatának kielemzésével. A tudásátadás új formája ez: látványos szemléltetés hatására aktivizálódik a tanuló, a problémának köszönhetően pedig számos kompetenciája - a probléma felfedezése, megoldása, elvont gondolkodás fejlesztése, döntéshozatali folyamat segítése és együttműködésre való hajlam növekedése - fejlődik. Mivel a terepasztalon lezajló természeti folyamatokat testközelben láthatják a diákok, így az észlelés és megfigyelés is új dimenzióba kerül. A diákokat sok esetben erősen motiválja az újszerű oktatási helyzet, gyakran a bemutató óra után is érdeklődést mutatnak, amit egy hagyományos földrajzóra után nem vagy csak ritkán tapasztalunk. Ez a fajta hozzáállás az ismeretek megszerzéséhez egyértelműen példa arra, hogy a magyar oktatási - és benne a föld rajzoktatási - rendszer túlságosan merev, illetve ismeret- és fogalomközpontú, továbbá jelentős részben tantervvezérelt, így nem sok lehetőséget ad a különböző innovációs megoldásokra, élményközpontú tanulásra. Nyilvánvalóan a problémaalapú tanulás oktatási módszerének beiktatása sem egyszerủ feladat, pedig már számos helyen, mint például Nyugat-Európában, ÉszakAmerikában vagy Ausztráliában az oktatáspolitika szorgalmazza (CASINDER, N. 2016, REINFried, S. 2004). Továbbá a diákok számára tanulságosabb egy ilyen jellegű szemléltető óra, és csökkentheti azt a már korábbi tanulmányok (például GARBINGER, S. R. 1996) által is felvetett jellegzetes problémát, hogy szakadék tátong az elméleti és a gyakorlati tudás között.

Egy geomodellekre alapuló óra segíti a fogalommegértést és annak alkalmazását, szelekcióját, illetve az összefüggések, kapcsolatok felismerését, rendszerben történő kezelését, és természetesen a tanulók tudásszerzési hatékonyságát. A terepasztal oktatási eredményei, illetve az azokból levont következtetések megerősítik, valamint igazolják a korábbi kutatási eredményeket a learning-by-doing módszer alkalmazhatóságát illetően mind a természettudományok egyéb területein, mind pedig a matematikában és a mérnöktudományokban (MAOR, D. - Fraser, B. J. 2005).

\section{Irodalom}

Agnew, C. 2001: Evaluating changes in learning and teaching. Journal of Geography in Higher Education 25. pp. 293-298. DOI: https://doi.org/10.1080/03098260120084377

Allen, D. E. - Duch, B. J. - Groh, S. E. 1996: The power of problem-based learning in teaching introductory science courses. New Directions for Teaching and Learning 68. pp. 43-52. DOI: https://doi. $\operatorname{org} / 10.1002 / \mathrm{tl} .37219966808$ 
ANDERson, R. D. 2006: Inquiry as an organising theme for science curricula. In: ABELL, S.-LEDERMAN, N. (szerk.): Handbook on research on science education. Routledge, New York-London. pp. 807-830.

Arts, J. A. R. - Gijselaers, W. H. - Segers, M. S. R. 2002: Cognitive effects of an authentic computer-supported, problem-based learning environment. Instructional Science 30. pp. 465-495. DOI: https:// doi.org/10.1023/A:1020532128625

Barron, B. - Darling-Hammond, L. 2008: How can we teach for meaningful learning? In DarlingHammond, L. - Barron, B. - Pearson, P. D. - Schoenfeld, A. H. - Stage, E. K. - Zimmerman, T. D. Cervetti, G. N. - Tilson, J. L. - Chen, M. (szerk.): Powerful learning. Jossey-Bass Wiley, San Francisco. pp. 11-70.

Barrows, H. S. - Tamblyn, R. M. 1980: Problem-based learning, an approach to medical education. Springer, New York

Bertalan L. - Tóth Cs. A. - Szabó G. - Nagy G. - Kuda F. - Szabó Sz. 2016: Confirmation of a theory: reconstruction of an alluvial plain development in a flume experiment. Erdkunde 70. 3. pp. 271-285.

Boud, D. - Feletti, G. (szerk.) 1991, 1997: The challenge of problem-based learning. Kogan Page, London CAsinder, N. 2016: Secondary geography and the Australian curriculum-directions in school implementation: a comparative study. International Research in Geographical and Environmental Education 25. 3. pp. 258-275. DOI: https://doi.org/10.1080/10382046.2016.1155325

Czigány Sz. - Pirkhoffer E. - Geresdi I. 2009: Environmental impacts of flash floods in Hungary. In: Samuels, P. - Huntington, S. - Allsop, W. - Harrop, J. (szerk.): Flood risk management: research - practice. Taylor-Francis Group, London. pp. 1439-1447.

GARbINGER, S. R. 1996: Rich environments for active learning. In: Jonassen, D. H. (szerk.): Handbook of research on educational communications and technology. Macmillan, New York. pp. 665-693.

Healey, M. - Jenkins A. 2000: Kolb's experiential learning theory and its application in geography in higher education. Journal of Geography 99. 5. pp. 185-195. DOI: https://doi.org/10.1080/00221340008978967

Hegedüs P. - Czigány Sz. - Balatonyi L. - Pirkhoffer E. - Ronczyk L. (2013): Estimation of flow rate calculation errors on the example of five rapid response catchments in the Mecsek Hills. Hungarian Geographical Bulletin 62. 4. pp. 331-350.

Jonassen, D. H. - Reeves, T. C. 1996: Learning with technology: Using computers as cognitive tools. In: Jonassen, D. H. (szerk.): Handbook of research for educational communications and technology. Macmillan, New York. pp. 693-719.

MolnÁr Gy. 2004: Problémamegoldás és probléma-alapú tanítás. Iskolakultúra. 14. 2. pp. 12-19.

MAOR, D. - Fraser, B. J. 2005: An online questionnaire for evaluating students' and teachers' perceptions of constructivist multimedia learning environments. Research in Science Education 35. 2-3. pp. 221-244. DOI: https://doi.org/10.1007/s11165-005-2148-3

NAGY L.-NÉ 2010: A kutatásalapú tanulás/tanítás ('inquiry based learning/teaching', IBL) és a természettudományok tanítása. Iskolakultúra 20. 12. pp. 31-51. 
Norton, S. N. - Ritchie, S. M. - Ginns, I. S. 2007: Design projects that integrate science and technology. In: Dawson, V. - Venville, G. (szerk.): The art of teaching primary school science. Allan \& Unwin, Crows Nest, pp. 202-215.

Pirkhoffer E. - Halmai Á. - Czigány Sz. - Bugya T. - Rábay A. - Bötkös T. - Nagy G. - Balassa B. - JANCSKárné AnWeiler I. - LóCzy D. 2014: New opportunities for experiments in fluvial geomorphology: The flume PTETHYS. Hungarian Geographical Bulletin 63. 4. pp. 1-12.

REINFrIED, S. 2004: Do curriculum reforms affect classroom teaching in geography? The case study of Switzerland. International Research in Geographical and Environmental Education 13. 3. pp. 239-250. DOI: https://doi.org/10.1080/10382040408668518

Schraw, G. - Crippen, K. J. - Hartley, K. 2006: Promoting self-regulation in science education: metacognition as part of a broader perspective on learning. Research in Science Education 36. 1. pp. 111-139. DOI: https://doi.org/10.1007/s11165-005-3917-8

Spronken-Smith, R. - Angelo, T. - Matthews, H. - O’steen, B. - Robertson, J. 2007: How effective is inquiry-based learning in linking teaching and research? International colloquium on international policies and practices for academic enquiry; Marwell, Winchester. Solent University Portal, Southampton. https://www.researchgate.net/profile/Rachel_Spronken-Smith/publication/237242449_How_Effective_ is_Inquiry-Based_Learning_in_Linking_Teaching_and_Research/links/5701db7d08ae1408e15eab64. pdf

Spronken-Smith, R. - Walker, R. - Batchelor, J. - O'steen, B. - Angelo, T. 2011: Enablers and constraints to the use of inquiry-based learning in undergraduate education. Teaching in Higher Education 16. 1. pp. 15-28. DOI: https://doi.org/10.1080/13562517.2010.507300

Spronken-Smith, R. - Walker, R. - Batchelor, J. - O’steen, B. - Angelo, T. 2012: Evaluating student perceptions of learning processes and intended learning outcomes under inquiry approaches. Assessment \& Evaluation in Higher Education 37. 1. pp. 57-72. DOI: https://doi.org/10.1080/02602938.2010.496531

Walton, H. J. - Matthews, M. B. 1989: Essentials of problem based learning. Medical Education 23. pp. 542-558. DOI: https://doi.org/10.1111/j.1365-2923.1989.tb01581.x

http://www.oecd.org/pisa/keyfindings/PISA-2012-results-volume-V.pdf

WATson, M. (2008). Inquiry based learning and university geography teaching. Technical report. https:// www.shef.ac.uk/polopoly_fs/1.122785!/file/Lit_review-IBLinGeography.pdf

\section{Köszönetnyilvánítás}

A szerzők hálás köszönetüket fejezik ki a kézirat bírálójának, amiért jelentős mértékben javította az eredeti változatot konstruktív javaslataival, valamint külön köszönet illeti az irodalomjegyzék javításáért is. A jelen tudományos közleményt a szerzők a Pécsi Tudományegyetem alapításának 650. évfordulója emlékének szentelik. 